\title{
SEJARAH PEMIKIRAN EKONOMI PADA MASA DINASTI
}

\section{Rizky Wahyuni}

\section{Masa Bani Umayyah}

Berikut Pemikiran-pemikiran Khalifah pada masa Bani Umayyah:

a. Khalifah Muawiyyah bin Abi Sofyan

Pada masa kepemimpinannya, Khalifah Muawiyah bin Abi Sofyan membangun tempat dinas dilengkapi dengan berbagai fasilitasnya, menertibkan angkatan perang, mencetak mata uang, dan mengembangkan jabatan qadi (hakim) sebagai jabatan profesional. Selain itu, khalifah Muawiyyah bin Abi Sofyan menerapkan kebijakan pemberian gaji tetap kepada para tentara, pembentukan tentara profesional, serta pengembangan birokrasi, seperti fungsi pengumpulan pajak dan administrasi politik.

b. Khalifah Abdul Malik bin Marwan

Pemikiran yang serius terhadap penertiban dan pengaturan uang dalam masyarakat Islam muncul di masa pemerintahan khalifah Abdul Malik bin Marwan. Hal ini dilatarbelakangi oleh permintaan pihak Romawi agar khalifah Abdul Malik bin Marwan menghapus kalimat Bismillahirrohmaanirrohiim dari mata uang yang berlaku pada khilafahnya. Pada saat itu, bangsa Romawi mengimpor dinar Islam dari Mesir. Akan tetapi, permintaan tersebut ditolaknya. Bahkan, khalifah Abdul Malik bin Marwan mencetak mata uang Islam tersendiri dengan tetap mencantumkan kalimat Bismillahirrohmanirrohim pada tahun $74 \mathrm{H}$ $(659 \mathrm{M})$ dan menyebarkannya ke seluruh wilayah Islam seraya melarang pemakaian melakukan percetakan mata uang lain. ia juga menjatuhkan hukuman ta'zir kepada mereka yang melakukan percetakan mata uang di luar percetakan Negara. Selain itu ia juga melakukan berbagai pembenahan administrasi pemerintahan dan memberlakukan bahasa Arab sebagai bahasa resmi administrsi pemerintahan Islam.

c. Khalifah Umar bin Abdul Aziz

Pada masa pemerintahannya, khalifah Umar bin Abdul Aziz memprioritaskan pembangunan dalam negeri. Di dalam melakukan berbagai kebijakannya, khalifah Umar bin Abdul Aziz bersifat melindungi dan maningkatkan kemakmuran taraf hidup masyarakat secara keseluruhan. Ia mengurangi beban pajak yang dipungut dari kaum Nasrani, menghapus pajak terhadap kaum Muslimin, membuat aturan takaran dan timbangan, membasmi cukai dan kerja paksa, memperbaiki tanah pertanian, penggalian sumursumur, pembangunan jalan-jalan, pembuatan tempat-tempat penginapan para musaffir, dan menyantuni fakir miskin. Berbagai kebijakan ini berhasil meningkatkan taraf hidup masyarakat secara keseluruhan hingga tidak ada lagi yang mau menerima zakat. ${ }^{1}$ Keinginan untuk mencapai Negara yang adil dan sejahtera dicapai Khalifah Umar bin Abdul Aziz dengan beberapa strategi kebijakan yang baru, diantara adalah: (1) Membagikan Kekayaan Negara dengan Rata dan Adil, (2) Kebijakan Baru dalam Bidang Pertanian dan Tanah, (3) Kebijakan pada Sumber

\footnotetext{
${ }^{1}$ Muhammad Nurul Huda, Sejarah Pemikiran Ekonomi Islam Pada Masa Daulah Bani Umayyah Dan Bani Abbasiyah, ESTORIA Vol. 1 No. 01, 2020, Hal. 95-100
} 
Penerimaan Negara, (4) Zakat, (5) Jizyah, (6) Kharaj, (7) 'Urs, (8) Al-Khums dari Ghanimah dan Fa'i. ${ }^{2}$

\section{Pada Masa Bani Abbasyiah}

a. Abu Ja'far Al-Manshur

kekhilafahan Bani Abbasiah masih mengalami ketidak seimbangan ekonomi, lemahnya pondasi kekhalifahan, banyaknya pemberontakan, namun setelah ia memimpin khilafah selama kurang lebih 22 tahun, beliau wafat dengan mewariskan Khilafah Abbasiah dalam keadaan mapan ekonomi, maju, kaya akan pengetahuan, memiliki peradaban yang megah, bahkan mencuri perhatian dunia akan kebesarannya. Dan ada pula keberhasilan yang diraih oleh Abu Ja'far Al-Manshur yaitu: (1) Pembangunan Kota Baghdad, (2) Majunya Ekonomi Negara, (3) Mendirikan Pusat Kajian Ilmu Pengetahuan.

b. Harun Ar-Rasyid

Pada masa Harun Ar-Rasyid menjabat sebagai Khalifah, Bani Abbasiah mencapai era keemasannya berkat kepiawannya dalam memerintah serta memimpin negara. Berikut keberhasilan yang diraih oleh harun ar-Rasyid,yaitu: (1) Memperindah kota Baghdad, (2) Mendirikan Rumah Sakit, (3) Mendirikan Khazanat Al-Hikmah. ${ }^{3}$ Sumber-sumber pemikiran ekonomi pada masa itu diperoleh dari sektor-sektor yang beragam, yaitu : 1. Perdagangan dan industri, 2. Pertaian dan perkebunna, 3. Perkembangan ilmu pertanian, 4. Pendapatan negara, 5. Sistem moneter. ${ }^{4}$

\section{Pada Masa Turki Utsmani}

Negara Utsmani muncul pada tahun $669 \mathrm{H}$. Akan tetapi, negara ini baru menganut sistem kekhalifahan pada tahun $923 \mathrm{H}$. Yakni saat transisi dari negara Islam menjadi kekhalifahan Islam, dan terus membela Islam sehingga lembaran sejarahnya ditutup pada tahun $1337 \mathrm{H}$. Pada masa Orkhan inilah dimulai usaha perluasan wilayah yang lebih agresip dibanding pada masa Usman. Dengan mengandalkan jennisary, Orkhan dapat menaklukan Azmir (Smirna) tahun 1327 M, Thawasyanly (1330 M), Uskandar (1338 M), Ankara (1354 M) dan Gallipoli (1356 M). Daerah-daerah ini merupakan bagian benua Eropa yang pertama kali diduduki oleh kerajaan Usmani. Kebesaran kerajaan Turki Usmani dicapai pada masa pemerintahan Sultan Muhammad II yang bergelar al-Fath, gelar ini diperoleh karena ia berhasil menaklukkan Konstatinopel pada 28 Mei 1453 M. dengan jatuhnya Konstatinopel yang kemudian beralih nama menjadi Istanbul merupakan saksi sejarah akan kebesaran kerajaan Usmani (Ottoman Empire). ${ }^{5}$

\footnotetext{
${ }^{2}$ Annisa Silvi Kusumastuti, Mohammad Ghozali, Konsep Welfare State Pada Kebijakan Pada Kebijakan Umar Bin Abdil Aziz Sebagai Khalifaj Bani Umayyah, LAA MAISYIR, Vol. 6, No. 2, 2019

${ }^{3}$ Abid Muhammad 'Ulwan, Peradaban dan Pemikiran Islam di Masa Kekhalifahan Bani Abbasiyah, Hal $8-12$

4 https://alawialbantani.blogspot.com/2018/08/sejarah-pemikiran-ekonomi-islam-aman.html (Di Akses Pada 31 Maret 2021 Pukul 14:16 WITA)

${ }^{5}$ Abi Suar, Pemikiran Ekonomi Islam Pada Masa Awal Turki Utsmani, Al-Dzahab, Vol. 1 (1) 2020, Hal. 


\section{DAFTAR PUSTAKA}

https://alawialbantani.blogspot.com/2018/08/sejarah-pemikiran-ekonomi-islamaman.html (Di Akses Pada 31 Maret 2021 Pukul 14:16 WITA)

Huda, M. N. (2020). SEJARAH PEMIKIRAN EKONOMI ISLAM PADA MASA DAULAH BANI UMAYYAH DAN BANI ABBASIYAH. Estoria: Journal of Social Science and Humanities, $1(1)$.

Kusumastuti, A. S., \& Ghozali, M. (2019). KONSEP WELFARE STATE PADA KEBIJAKAN UMAR BIN ABDIL AZIZ SEBAGAI KHALIFAH BANI UMAYYAH. Laa Maisyir: Jurnal Ekonomi Islam, 6(2), 282-296.

MUHAMMAD‘ULWAN, A. D. I. B. PERADABAN DAN PEMIKIRAN ISLAM DI MASA KEKHALIFAHAN BANI ABBASIAH.

Suar, A. (2020). PEMIKIRAN EKONOMI ISLAM PADA MASA AWAL TURKI UTSMANI. AL DZAHAB ISLAMIC ECONOMY JOURNAL, 1(1), 53-71. 